\title{
Overshadowed by Neo-Orientalism: The Odyssey in Fadia Faqir's Willow Trees Don't Weep
} Ikram Ahmed Elsherif

Associate Professor, Faculty of languages, October University for Modern Sciences and Arts (MSA), Egypt.

\begin{abstract}
The work of Anglophone Arab women writers, especially after the attacks of 9/11, 2001, attracted and still attracts a lot of attention in the West because it potentially offers an opportunity for western audiences to have access to and understand the Arab world. However, instead of paving the way for better understanding of and communication with Arab culture, this work, written from what Homi Bhabha calls the "Third Space of enunciation", a place of liminality and hybridity, may conversely promote and recycle western neo-Orientalist stereotypical views about the Arab world and its culture, distract readers from grasping the work's deeper issues and invite reductionist, orientalist readings which rob it of much of its depth and human value. This paper analyzes the novel Willow Trees Don't Weep, by the Jordanian-British writer Fadia Faqir, to explore and expose the tension between the neo-Orientalist representations of her characters, both female and male, and the deeper expression of their human subjectivity. It argues that, taken at face value and given the fact that Faqir is preoccupied with problems of gender and patriarchy, the novel may be read and interpreted as reiterating neo-Orientalist stereotypical preconceptions of Arab/Muslim oppression of women. However, on a deeper level, Faqir appears to be more concerned with her two main characters' (a father and daughter) expression of human agency as they embark on Odyssean heroic journeys of self-discovery and enlightenment, comparable to the classical hero's journey as discussed by Joseph Campbell in The Hero with a Thousand Faces, that humanize and help them to heal and be re-conciliated to self and other.
\end{abstract}


In the aftermath of the tragic events of 9/11, 2001, attention to and interest in the work of Anglophone Arab writers in the West started to accelerate as, according to Susan Muaddi Darraj in "Writing Relocation", Western readers sought "to understand the 'Arab mind' and the Arab world." This accelerating interest gives Anglophone Arab literature a special importance "because it bypasses the need for translation and, poised between East and West, speaks directly to English speaking audiences about the world on the other side of the divide" (123). However, with 'special' importance comes a risk and a huge responsibility. 'Poised between East and West', Anglophone Arab writers write from what Homi Bhabha calls "the Third Space of enunciation" (37), a hybrid space of liminality which allows them "to approach their tradition from a transcultural perspective" (Suyoufie 226). Their representations of their cultures and traditions are, thus, bound to be influenced by Western perspectives which still perpetuate orientalist, colonial/postcolonial views and ideologies about the East, particularly the Arab and Muslim world. In reevaluating aspects of their societies and traditions which they might deem problematic or oppressive, Anglophone Arab writers may be unwittingly recycling stereotypical images of the Arab world, further feeding the preconceived assumptions of their Western audience. Conversely, Rachel Bower explains, authors "who must ultimately sell" their books may bend to "market imperatives" to produce a "consumable impression of the Arab world" (4-5). In any case, even if they are wary of the pitfalls of their liminal position and hybrid consciousness, writers, especially women writers, who attempt to negotiate patriarchal and gender relations in the Arab world, for example, may find their work, as Amal Amireh points out, "marketed" and "manipulated" (n.p.) not only to feed "the existing stereotypes of Arabs and Muslims as backward, misogynist, and violently oppressive" (n.p), but also to serve a Western political agenda. The work of the Anglophone Jordanian-British writer Fadia Faqir is a case in point.

Fadia Faqir was born in 1956 in Amman, Jordan, to a conservative Muslim family with whose strict patriarchal rules she was always at odds. After graduating from the University of Jordan, Amman, with a BA in English Literature, Faqir traveled to the UK to pursue her postgraduate studies in creative writing and obtained an MA from the University of Lancaster and a PhD from the University of East Angelia. She is now a Writing Fellow at St Aidan's College, Durham University. Her academic research as well as her works of fiction tackle issue of gender, violence against women, patriarchy and Islamic traditions. However, it is particularly her most popular and renowned novels, Pillars of Salt (1996), My Name Is Salma (2007) and Willow Trees Don't Weep (2014), that have earned her recognition as "a defender of human rights, especially those of women in Arab countries" (El Miniawi 36). These novels represent the struggles of her heroines in her patriarchal Jordanian society, and though highly acclaimed in the West, they have also been accused, as pointed out by Bower in her interview with Faqir in 2010, of "perpetuating Orientalist stereotypes about Arab oppression of women." Faqir's response to this accusation is worth noting:

It is important to be self-critical. There will be no reform without that. Yet the way issues are tackled is important. I'm not an Orientalist or an Islam basher. I write about the Arab world because I love it and because I have a deep desire to change it for the better. Perhaps it is all about motivation. Are you maliciously misrepresenting the Arabs or are you driven by a desire for change? I am aware of the pitfalls and I walk that tight-rope every day." (9) 
The accusation and response here necessarily pose the questions: is Faqir truly aware of the pitfalls of her position as an Anglophone Arab Woman writer in the West? Or has her 'deep desire' for change caused her to fall, aware or unaware, into the pitfall of the neo-Orientalist discourse of the post-9/11 political and cultural turmoil? Has she succeeded in giving authentic representations of the human agency and subjective experiences of her characters? Or do her representations have the quality of sweeping generalizations that can be both misconceived and exploited?

This paper attempts an intensive analysis of Faqir's Willow Trees Don't Weep to explore and expose the tension between the neo-Orientalist representations of her characters, both female and male, and the deeper expression of their human subjectivity. It argues that, taken at face value and given the fact that Faqir is preoccupied with problems of gender and patriarchy, the novel may be read and interpreted as reiterating neo-Orientalist stereotypical preconceptions of Arab/Muslim oppression of women. However, on a deeper level, Faqir appears to be more concerned with her two main characters' (a father and daughter) expression of human agency as they embark on Odyssean heroic journeys of self-discovery and enlightenment comparable to the classical hero's journey as discussed by Joseph Campbell in The Hero with a Thousand Faces.

When Edward Said wrote about the Orient or the East, as portrayed by Europeans, in his seminal work Orientalism, he maintained that it was "a European invention," or "a European representation" of "the place of Europe's greatest and richest and oldest colonies ... and one of its deepest and most recurring images of the Other" (1). This European representation gave rise to Orientalism, a "system of knowledge about the Orient" which not only seeped and took root into "western consciousness," but which was also employed in the service of western "socio-economic and political institutions," seeking to dominate, restructure and have authority over the Orient "by reiterating European superiority over Oriental backwardness" (6-7). Orientalism thus both reflected the western experience of the Orient which excluded the voice of the Oriental, and promoted Western hegemony and justified colonial enterprise.

With the waning of colonialism, and as the world became subject to shifting global political changes, as Mubarak Altwaiji contends, "the term Orient" and "its geography" are "reconsidered and reshaped." Altwaiji pinpoints the 9/11 terrorist attacks and U.S. military retaliation as a point in history affecting a re-evaluation of the classic Orient and the emergence of neo-Orientalism (314) to serve and "facilitate new imperialistic strategies that aim at dominating new regions" (319). Neo-Orientalism resuscitates the same Orientalist binary opposition of West and East, 'us' and 'them'; however, it is characterized by two main differences from classical Orientalism: First, according to Khalid M. Alrasheed, "in classical Orientalism, most third world cultures were subjects of interest and they are still [,] but after 9/11 Arab/Muslim traditions become central to the analysis of neo-Orientalism" (10). The second most significant difference is that pointed out by Ali Behdad and Juliet Williams:

Whereas classical Orientalists were commonly male European savants, philologists, established writers and artists, neo-Orientalists tend to be ordinary Middle Eastern subjects whose self-proclaimed authenticity sanctions and authorizes their discourse. Contemporary neo-Orientalists are Middle Eastern women and men who use their native subjectivity and new-found agency in the West to render otherwise biased accounts of the region seemly more authoritative and objective. (284) 
Probably the most dangerous of these two differences between classical and neo-Orientalism is the second, the authoritative voice of the Middle Eastern neo-Orientalists who are dubbed, by Hamid Dabashi, "native informers turned comprador intellectuals" because they have been "there" and they supposedly know what they are "talking about." Thus their 'biased accounts' which are received as 'authentic' might play a critical role in the balance of power and domination as they, Dabashi maintains, "normalise the imperial centre and cast its peripheral boundaries as odd, abnormal, and grotesque" and thus facilitate "public consent to imperial hubris" (n.p.).

Muslim and Arab women and their position within their cultures and societies have always been at the heart of classical as well as neo-Orientalist representations of the East and Islam. Amireh writes:

Historically, the west's interest in Arab women is part of its interest in and hostility to Islam. This hostility was central to the colonialist project, which cast women as victims to be rescued from Muslim male violence. The fixation on the veil, the harem, excision, and polygamy made Arab women symbols of a region and a religion that were at once exotic, violent and inferior. (n.p.)

This 'interest' in Muslim Arab women has resurged after 9/11 on the political, cultural and academic levels. For example, implicitly falling back on the rhetoric of 'the white man's burden' to champion the cause of oppressed Muslim women, Laura Bush, George W. Bush's wife, in her address to the nation in November, 2001, dragged Muslim women right into the fray of political conflict by stating that "the fight against terrorism is also a fight for the rights and dignity of women" (n.p). Bernard Lewis buttresses and validates this underlying rhetoric in his book, What Went Wrong? (2003), where he blatantly asserts that "the most profound single difference" that marks the superiority of the West over the Islamic East is the way they treat women. He claims that "in Islamic law and traditions there are three groups of people who did not benefit from the general Muslim principle of legal and religious equality-unbelievers, slaves and women," and that woman is the "worst-placed of the three" because while "slaves could be freed" and "the unbeliever could at any time become a believer," Muslim "woman was doomed forever to remain what she was" (67-69), that is inferior, oppressed and excluded. Within this imperialistic and neoOrientalist context the literary production of Arab Anglophone writers, especially women writers like Fadia Faqir, plays a crucial role. In classical Orientalist discourse the Arab/Muslim/Eastern woman, as Said contends, "never spoke for herself, she never represented her emotions, presence, or history." It was the European Orientalist who, being "foreign, comparatively wealthy, male," possessed the "historical facts of domination that allowed him ... to speak for her and tell his readers in what ways she was 'typically Oriental"' (6). However, it is probably these same facts, which put the classical Orientalist in a position of domination, that also inherently open the door for "a more independent, or skeptical, thinker" (7) to critique and contest his representation. The case of an Anglophone Arab woman writer's neo-Orientalist representations is more problematic. She, unlike the 'foreign, male' Orientalist, is a woman and a native who speaks for herself, and thus she supposedly, as Dabashi puts it, speaks "with the voice of authenticity" (n.p.). Therefore, her representations of Arab/Muslim women and their experiences would not only seem above contestation, but could also be exploited and manipulated in the service of Western political and cultural hegemony.

In an interview with Lindsey Moore in 2010, Fadia Faqir asserted that “Arab women's writing [in the West] sells more" and that this demand stems from western "preconceived ideas 
about Arab women: they're oppressed; they're all veiled against their will." Anglophone Arab women's writing is particularly "intriguing" for western audience as it offers them an opportunity to "lift the veil" to reveal and maybe also liberate those exotic, oppressed beings. This western neo-Orientalist attitude is reflected in how Faqir's novels are marketed. All her novels, she says, "have veiled women on the cover." However, she also asserts that she does not "see all of them [the covers] before they get published and I don't approve of them" because "the women in my books are not usually veiled: they either reject the veil or don't think about it. Other issues concern them. Yet the reduction continues" (5-6). Since, as Amireh maintains, "reviewers of Arab women's books seem to take their cues from the titles and covers" (n.p.), these reviewers more often than not approach the works with their orientalist preconceptions and expectations ready and sharpened. Thus, no matter what "other issues" Faqir and her heroines are concerned with and no matter how complex and intertwined these issues and concerns are, Western Orientalism zooms on the veil and preconceived notions of female oppression, reducing the Arab woman/heroine to no more than what Darraj calls, in Scheherazade's Legacy, "an exotic, shallow, sex-crazed body behind a veil" (1).

This reductionist mis/preconception extends to Faqir's Willow Trees Don't Weep, a novel which weaves an intricate web where the personal and the psychological history of the characters intertwines with political history, religion and culture. However, in spite of, or probably because of, the ambitious web of nuanced issues and characters the novel presents, readers tend to overlook the deeper issues and pick on the obvious and readily available orientalist images which feed and confirm their preconceptions. The Mauritian popular fiction writer Sophie Cayeux, for example, comments in her review of the novel: "The author's description of the plight and helplessness of women is heartbreaking. The fact that protection by a man is mandatory for any woman's safety is such a frightening and awful concept for those of us who are lucky not to live in such societies" (n. p.). The othering binary opposition of 'us who are lucky' and 'them who are helpless' not only reflects Cayeux's condescending attitude, but also strips the novel of its complexity and the characters of their depths. This is also echoed in a more recent review of the novel. Sourav Paul and Shri Krishan Rai write,

The issue of sexual violence (not merely harassment) is astoundly prominent in the broader literary landscape of the Middle East. Fadia Faqir's Willow Trees Don't Weep is a blistering broadside on socially sanctioned abuse of womanhood in an Islamic state. It is an account of how women are hunted, chocked, chopped up, and thrown away. (132)

Faqir does weave issues of patriarchy, gender, honor crimes and sexual harassment in the novel; however, she neither represents her main female characters as 'helpless', nor does she show them as being 'hunted, chocked, chopped up, and thrown away'. As a matter of fact, the novel explores complex and overlapping issues of politics, religion, family, abandonment and loss out of which the female characters come through as subjects of considerable strength and resilience. In an interview with Fadi Zaghmout in 2015 Faqir explained what urged her to write the novel:

When I heard that a young man from our neighbourhood in Amman 'achieved martyrdom' in Afghanistan in 1987 my fourth novel [Willow Trees Don't Weep] began germinating. I was puzzled by this piece of news. Why would a young man from Jordan travel all the way to Afghanistan to fight somebody else's war? How could he leave his family and country behind and travel with the Taliban from one 
province to another, looking for Soviets and their supports? What happens to your loved ones when you prioritize the call to jihad, holy war, over them? What about their women relatives who are left to fend for themselves, earn a living, and keep the household together? Their perspectives were mostly missing in everything I had heard or read. (n.p.)

Attempting to answer these questions and fill in the void of the missing perspectives, the novel features two intertwined first person narratives of a father who abandoned his family for Jihad and his wife and daughter's reaction to that abandonment. Though the novel does explore issues of gender and patriarchy, the focus is mainly on the relationship of the father and daughter who take similar journeys, treading the same psychological and physical terrains. Willow Trees Don't Weep presents itself as a modern odyssey, or rather two odysseys, two parallel journeys and existential quests for identity and meaning undertaken by the heroine, Najwa, and her father, Omar Rahman, who follow the three stages of the monomythic hero's journey as defined by Joseph Campbell in The Hero with a Thousand Faces.

Willow Trees Don't Weep is the story of Najwa, a 27 years old young woman from Jordan, and her family, particularly her father Omar Rahman. The novel begins with the death of Raneen, Najwa's mother, after a long battle with cancer. The events of the past and the present unfold through the alternating voices of Najwa and her father. In 1986, When Najwa was three, Omar abandoned his wife and daughter to travel to Afghanistan and join a Jihadist group, and his departure turns his wife's and daughter's life upside-down. Raneen becomes "the imposer of rules and regulations" in the household that is now matriarchal, made up of her, her own mother Mama Zainab, and Najwa. Resenting religion and blaming it for her husband's departure, she turns her household "secular," allowing "no religious words, deeds, texts, symbols, jewellery or dress in this house" (9). Raneen isolates herself and her daughter from their religious community, forbids Najwa from wearing the veil and from participating in any social religious practices. She even compels Najwa to study and train as a tourist guide to work in one of the hotels by the Dead Sea because it is one of "the most cosmopolitan and secular environments" (10). Eventually, consumed by bitterness and disappointment she falls victim to cancer which claims her life.

Living from age three to twenty-seven under her mother's obsessive strict secular rules with no father to "dampen" her mother's "temper" (14), Najwa felt "like a prisoner, condemned to my life" (5). Though she saw herself "as different from what she [her mother] planned or envisaged" (10) for her, she was compelled to surrender to her mother's will, thus always feeling lost, vulnerable and insecure, "caught in the middle" between her mother's secularism and her religious community's rules which decreed that for a young woman with "no male guardian, [there was] no honour, no status in this neigbourhood" (5). Najwa's real plight, however, is her inability to define her self and find her own place in the world. The death of her mother ushers in a new phase in her life. Her grandmother, Mama Zainab, confronts her with what she already knows, that her mother is dead, that she, the grandmother, is old and will eventually pass away, and that Najwa will be left alone without a male guardian and "tongues will wag" (6). Her only option is to go out in search of her father, a search that would help her "construct a father" (34), a "past [that] might make you whole" (28) and discover "who made that web you find yourself caught in" and whether she could "soar solo" (15). Thus she sells the family gold heirlooms, sends her grandmother to Mecca to perform the Haj and embarks on her "own pilgrimage" (104) that takes her from Amman to Pakistan to Afghanistan to London. 
The story of Najwa's father, Omar Rahman, is revealed from the excerpts of his diary that are inserted within Najwa's narrative. When he left his family in 1986, he was probably the same age Najwa is when she starts her journey. Like Najwa, Omar begins as a secular young man who was studying to become a nurse to save lives. He and his friend, Hani, were romantic dreamers who believed themselves to be the "secular ... holders of the mighty pen" who would be the "avant-garde, the anti-capitalist, anti-imperialist" founders of Xanadu, "the cosmopolis we wish for and desire" where "degradation of human life" could be stopped (60). However, "an uptight, frigid wife; economic problems: prospects of no job after graduation; political problems: the Sultan ruling supreme" (81) made Xanadu an almost impossible dream at home. When his friend Hani, atoning for the guilt of having had a casual sexual relationship with an American girl, joins a religious group, is arrested, "tortured and violated by the secret police" (246), Omar is struck by his "impotence and powerlessness" (82) and "let[ting] go of the self he knew", decides to follow "his heart and travel with Hani" (116) to Afghanistan in search of the Xanadu he had always dreamed of.

To explore the political, social and psychological causes and ramifications of Omar's decision, Faqir unfolds the story through the two parallel first person narratives of Najwa and Omar. The story of Omar is threaded through the story of Najwa as, searching for him, she treads the same terrain that he had followed years ago after abandoning her and her mother to follow and protect his friend Hani. The two narratives, which converge when they finally meet at the end, reveal that the physical journeys they embark on parallel also their inner journeys. And though they are ordinary human beings in modern society, their stories echo those great hero epics of old which, Donna Rosenberg explains,

address fundamental questions that each thinking person continues to ask: who am I? what is the nature of the universe in which I live? How do I relate to that universe? How much control do I have over my own life? What might I do in order to survive? How can I balance my own desires with my responsibilities to my family and my community? How can I reconcile myself to the inevitability of death? (xv-xvi)

Since all hero journeys and stories are incited by and unfold in response to similar existentialist questions (Estés, xlvii-xlviii), Najwa and Omar, who are constantly questioning their identities, their position in the world and their responsibilities, go out on a quest searching for a secure sense of self and a meaning to their lives. Their journeys and quests follow the stages of the hero's journey as defined by Joseph Campbell.

According to Campbell, the hero "and/or the world in which he finds himself suffers from a symbolical deficiency" (35); and this deficiency is what ignites his questions and his quest for answers, urging him to journey. The hero's journey "may be over-ground, incidentally; fundamentally it is inward-into depths where obscure resistances are overcome, and long lost, forgotten powers are revivified, to be made available for the transfiguration of the world" (27). The journey consists of three major stages: "Separation and Departure", "Trials and Victories of Initiation", and "Return and Reintegration with Society". Each stage has several elements that may not, however, be included in all hero journeys, and sometimes these elements do not happen in a specific order. What is constant in all journeys are the three major stages (33-35).

Both Najwa and her father find themselves in a world and under conditions which give them no sense of self and no satisfaction and they are beset with questions that seem to have no 
answers. Abandoned by her father at age three and controlled by a bitter obsessive mother, Najwa wonders if she was ever loved or wanted, "was I conceived by mistake or design? Did my parents want me?" (26). Furthermore, living without the guidance of a father and with a mother who has walled herself in and was consumed by her own disappointments, she lacked a road map to the world which, for her, is "a maze and I didn't know where to enter it, how to navigate it and whether I would find a way out" (23). Even in matters of religion and belief, Najwa is confused and uncertain, "Was I a Muslim? Why did I find bowing to Allah difficult, even humiliating?" (111), "What was I? A believer or a non-believer? Did I have faith? Was being secular a sin? Was it imposed on me by my late mother?" (138). The death of her mother has a paradoxical effect on Najwa. On the one hand, without Raneen's protective, though limiting, rules, Najwa is lost in an uncertain world. On the other hand, she is simultaneously set free to explore life and, as Faqir says, "navigate a way ... and forge her own ethical code" (Zaghmout n.p.). Mama Zainab, urging her to search for her father, signals the first stage of her journey, the "departure and initiation" which begins with the "call for adventure" that, according to Campbell, "signifies that destiny has summoned the hero and transferred his spiritual center of gravity from the pale of his society to a zone unknown" (55).

Similarly, Omar was equally confused and uncertain. A young "man who wanted to walk around the world ... to be a Passepartout, a traveller with little luggage ... a Thomas Cook, an Ibn Battuta," Omar found himself at approximately Najwa's age burdened with the responsibility of a "sulking wife, screaming baby and an old woman sniveling in the kitchen," and wonders "How did I find myself here? Where is Xanadu?" He usually found an outlet from an oppressive domestic, economic and political life in writing in his diary, but for him this was "an act of a small man-poor, subjugated and powerless" (33). However, when Hani is arrested and violated, becoming "a shadow of his former self" (80), Omar himself is shattered, and his self splits into two, the self he knew and an "alien" self that he had "never seen before" (82). Torn between his responsibility for his family and an "unexplained compulsion" (81) to go with Hani, Omar questions himself and his motives: was he putting Hani and his family on a scale? Was he escaping his "obsessive wife and ordinary life?" (117). Unable to find answers, he, like Najwa, is summoned by destiny to go "searching for new possibilities" (82).

With a space of almost 25 years separating the beginning of their respective journeys of initiation, Omar and Najwa cross the threshold between two worlds, the world they know and the unknown world of danger and trials where they will be tested and transformed. Najwa's detailed descriptions of her entry into that world, starting from her departure from Jordan and crossing borders into Pakistan, Afghanistan and finally England, gives insight into her father's journey as she traverses the same physical borders and spaces. Arriving in Afghanistan into the same Mujahedeen camp where her father had lived for many years, Najwa, steps into "the belly of the whale", this unknown region which threatens to "swallow" the hero. It is here that the hero, Najwa like her father before her, begins the "road of trials" and "moves in a dream landscape of curiously fluid, ambiguous forms, where he must survive a succession of trials" (Campbell 83-89).

In the Mujahedeen camp, in Part IV of the novel which is ironically titled "Xanadu", both Najwa and Omar are tested almost to the limit both physically and psychologically. In this camp Omar lived among the devastation, destruction and gore of war functioning as a "Doktor", constantly asking himself "what the hell am I doing in this country?... What am I fighting for?" (116) and "tried to resist becoming a combatant" (158). However, the brutal torture and murder of his friend Hani at the hands of American and English troops tips him over the edge and turns 
him into "a werewolf past midnight; I howled" (159). Omar's devastating experiences bring him "all the way from healing to hurting" (194), from "an angel of mercy to one of wrath" who wants to "punish the English for the death and destruction their army had visited on Afghanistan" (248). Thus, he goes to England where he masterminds a terrorist attack that leaves tens of innocent civilians dead or injured. The transformation of Omar from a healer to a terrorist reflects his failure on what Campbell calls the "really perilous path of initiatory conquests and moments of illumination." His disappointment at not finding his dreamed of Xanadu and his personal grief over the brutal death of his friend makes it difficult for his "ego [to] put itself to death" (100) and all he can think of is retaliation, reproducing the atrocities he was retaliating against, which ironically contributes to the annihilation of the dream of the Xanadu, the cosmopolis where 'human degradation could be stopped'.

In the same Mujahedeen camp where she has traced her father, Najwa also experiences similar failures. Arriving to find her father gone, leaving behind a second wife, Gulnar, and another young daughter, Amani, Najwa is overcome with anger, jealousy and envy, which blind her to all Gulnar's kindness and Amani's vulnerability and need for love. All she can see in Amani is a girl who was "showered ... with love" (151), while her own "parents were absent: my father was away and my mother was drugged most of the time." Thus "sick with envy," Najwa could not let go of her selfish grief to realize that Amani shared her plight and was "desperate to be accepted" (153). After Amani dies in a bombing attack, Najwa leaves the camp to pursue her father to England, carrying with her additional feelings of guilt, a letter Amani had written to their father and intensified anger and resentment against him. In England, after many difficulties she comes to know that he is in prison for the terrorist attack he masterminded, and with the help of many kind strangers she manages to visit him. The first visit is another trial in which she fails to go past her ego and her anger. Instead of being open for understanding and forgiveness, she hurls at Omar the news that Amani was killed, blames him for her death and the death of her own mother and tells him that she came only to give him the letter Amani had written. Just as Omar wanted to retaliate and project his pain on those he blamed for the death of Hani and the atrocities he witnessed in Afghanistan, Najwa also wants to retaliate and project her pain on the father who abandoned her.

"Apotheosis," which Campbell defines as the "pattern of divine state [of understanding and illumination] to which the human hero attains" after he "has gone beyond the last terrors of ignorance" (139) is attained by Najwa and Omar after their first meeting. Omar, shaken to the core by the cruelty of the daughter he remembers as a "soft and malleable" (29) baby "fluttering in my hands like a sparrow," is forced into self-confrontation and self-reckoning. He acknowledges that "there is a schism between the man I hoped I would be and the man I finally became," understands that "if Najwa is cruel, then I am to blame," and that his wife's obsessive and controlling behavior was the defensive mechanism of a woman who lost her father at a very young age, a loss that "stripped her of all feelings of safety and security" (246). Equally important, he also realizes that he and Hani were "young and trusting" and were "duped, brainwashed and even exploited by the imams." Omar understands and delivers the message Faqir intended him to convey, "you don't liberate a country standing on the soil of another" (246). Wanting to atone for what he now understands as "reactive" moves that he took "without much consideration or critical thinking" (247), Omar admits and accepts responsibility for the violence he committed, and regains his sense of responsibility towards Najwa and arranges for her to live a stable and secure life with Hani's parents when she goes back to Jordan. 
Najwa's apotheosis, her triumph over the "terrors of ignorance", however, did not need a cruel action to be accomplished. What leads her to illumination is the "intercession" of her "helpful female figure" (Campbell 120), Mama Zainab, who sends her the box containing all the photos, letters and gifts her father used to send her and which her mother tried to destroy, but were salvaged and kept by Mama Zainab. It is her family's "past, crammed in there for years" (257) and now presenting itself to her that functions as the "magic ... charm" (Campbell 120) that finally makes "atonement with the father" possible, liberates Najwa and gives her the insight she needed to heal. Her father's letters reveal his love for her and her mother, his regrets, doubts fears and weaknesses. They, as Campbell puts it, ameliorate "the ogre aspect of the father" (119), humanize him for her and she does not need to ask again, "who was Omar Rahman? A murderer? A babyabandoner? A wife-jilter? Or a revolutionary? A chaser of dreams and wider horizons?" (65-66). She realizes that, as a complex human being, he is a mesh of all that. Enlightened, Najwa can put the past in perspective and finally feels located in time and space: "Here and now, I- the skin, gristle, bone and blood of me-seemed real" (261). Knowing the past and coming to terms with it, she gains a solid sense of self, and is now ready to forgive and to heal. Her father's "treachery tucked away in the other life" (265) and her own guilt over the "awful things" she did admitted and forgiven (254), Najwa could finally cry, but not only for herself:

I wept over the father who stood before me, a convicted criminal; my mother, who spent most of her life drugged and died prematurely; our neighbour's son, who wouldn't get married to a girl brought up in a house without men; Andy's rejection; over my half-sister, who was desperate for my love and never received it, and over my stepmother, whose daughter's death unhinged her. I cried over my grandmother, who had lost her husband in the war, then her homeland, and who had to wait most of her life to do the haj. Cancer, death, suicide bombs, drones and blown-up buses. I howled. (266)

Willow Trees Don't Weep, as Faqir herself declared, is "a rite of passage and a narrative of initiation. Physical journeys from one country and continent to another are intertwined with internal ones. The odyssey humanizes and leads towards compassion for self and others and ultimately forgiveness" (Zaghmout n.p.). Both Najwa and Omar attain enlightenment and a deeper sense of humanity at the end of their journeys, but while Omar still has to atone for his failures, Najwa wins the "Ultimate Boon", the "elixir", the "sustaining power" and "grace of indestructible life" (Campbell 160/167). With a solid sense of self and secure in the knowledge that her father has arranged for her a socially acceptable life in her own country, she is ready for "Return and Reintegration with society". Yet, psychological healing and a defined identity are not the only thing she takes back, for Omar gives her his diary, a document of his life and history "stained" with "Hani's blood," a "legacy" (270), or what Campbell calls a "symbol of office." It is a gift of "initiation" which is

an introduction of the candidate into the techniques, duties, and prerogatives of his vocation with a radical readjustment of his emotional relationship to the parental images. The mystagogue (father or father-substitute) is to entrust the symbols of office only to a son [or daughter in this case] who has been effectually purged of all inappropriate infantile cathexes - for whom the just, impersonal exercise of power will not be rendered impossible by unconscious (or conscious and rationalized) motives of self-aggrandizement, personal preferences, or resentments. (125) 
Omar's diary encloses his experiences, his insights and his enlightened humanity which will fill in the gaps in Najwa's history, help her answer the questions she started off with, and inform and guide her future. It initiates her into the adult world to assume her 'office' or responsibility as a human being and possibly even take on the 'duties' that her father, himself, neglected. Thus, acknowledging her responsibility for the dead and the living, she prepares to go back to "sweep my mother's grave" (276), take care of her grandmother, and probably also pass on the wisdom she and her father gained from their experiences.

The novel ends with Najwa preparing to go back to Jordan, an ending which Flemmich Webb finds disappointedly "underwhelming" (n.p.). Webb's comment seems justifiable in view of the fact that most reviews and critical analyses of the novel build on the premises that "Najwa's journey in tracing her father [i]s a journey of finding home to [sic] her unprotected femininity" (Ouahmiche and Sarnou 146) and an attempt at resisting "male domination in a patriarchal society that ... [treats] woman as [an] inferior being" (Rosida and Soraya 14). For Najwa, after her long journey and varied experiences, to choose to go back to live under the protection of Hani's parents and surrender to the dictates of her patriarchal community which affords women "no honour and no status' without a male guardian, would indeed seem disappointing from orientalist and feminist perspectives because she seems to "restore back the patriarchy" that her mother excluded from their house (Ouahmiche and Sarnou 146). For Webb, and a number of other reviewers, then, Faqir "fails to capitalise" (n.p.) on the problems of patriarchy and gender oppression. This, too, seems justifiable since Faqir, as Fadia Suyoufie rightly points out, in her "eagerness to apply self-critique as a strategy" to expose oppressive social and cultural practices in her country, focuses "on the negative aspects of Arab culture" (247) and recycles "Orientalist views of the East and its women" (228). Faqir does indeed repetitively emphasize, especially in the first part of the novel, Najwa's heightened sense of oppression and sexual harassment to the point where it sometimes seems illogical. For instance, on two separate occasions, before she goes out in search of her father, Najwa is harassed by a taxi driver who "ogled me in the mirror" (15) and a man in a passing car who makes a pass at her (26). On the two occasions the men are strangers who do not know her, yet Najwa immediately thinks this happens because she is "the daughter of an absent father" and therefore is considered "common land, without a fence or borders" (15). Faqir's emphasis on Najwa's sense of vulnerability as a fatherless single woman may be her way of bringing to the limelight the deep sense of insecurity Najwa grew up with. However, this repetitive emphasis, coupled with instances of forced and abrupt inclusion of comments, for example, about "a young woman, perhaps thirteen of fourteen, with multiple stab wounds" who was "obviously a victim of an honour killing" (18), may compromise the deeper aim and message of the novel. On the one hand, they confirm her audience's orientalist views; and on the other, they are potentially distracting as they direct the audience's attention away from not only Faqir's aim of exploring the ramifications of Omar's prioritizing the call for Jihad over his family, but also from the human significance of his and Najwa's journeys.

It is important to note at this point that Faqir's insistent comments on oppressive patriarchal practices may also undermine the image of her female characters as strong women and, as indicated above, promote her reader's perception of them as "helpless" victims. The matriarchal household in which Najwa lived, however, belies this perception. Mama Zainab, the warm mother, grandmother and "most beautiful mother-in-law in the world" (82), as Omar calls her, who endured the loss of husband, country and daughter, could still nurture. She "knew who she was, where she came from and what she believed in" (138) and this secure knowledge of self is what helped her 
survive, support her daughter throughout her disappointments and sickness, and guide Najwa to the path of wholeness. Even Raneen, Najwa's mother, though represented as disappointed, obsessive and insecure, has her own brand of strength which is very telling and enlightening. Turning "secular" in a religious patriarchal community, Raneen should have been ostracized by her community, but it is obvious that the opposite is true. She is the one who defies and ostracizes the community, refusing "to have anything to do with" them (66). She takes off her veil and prevents her daughter and mother from practicing religion in her house. She shuts out the community and its rules, denies her friendly religious neighbor access to her home and life, and she works to support herself and her family. It is she, not the community, who makes the rules in her life, yet she is tolerated. Although devastated by her husband's abandonment, Raneen does survive, at least until she has made sure that her daughter is not offered "on a plate to the nasty sheiks" (24). Even admitting at her deathbed that she allowed herself to "dry up like a date" and urging Najwa, "don't be like me" (16), requires a measure of strength. If Raneen is portrayed as a victim, she is not a victim of her patriarchal society, but of her bitter disappointment in the husband whom she loved and who abandoned her.

Najwa also is anything but a helpless woman. Her strength and unfaltering determination can be summarized in her ability, to borrow from Alfred, Lord Tennyson's "Ulysses", "To strive, to seek, to find and not to yield." Breaking many of her society's rules even before beginning her journey (52), braving the dangers of the journey into an unknown world, finding her father against the odds and not yielding to frustration, fear or illness, and finally, and most importantly, not yielding to her egotistic resentments, Najwa "wounded, yet standing" (276), achieves illumination that is implied in her final decision to return to her own known world. Rather than choosing to remain in England, she decides to go back to honor the memory of her mother, take care of her grandmother, and make money to bring her father home if he is ever released. This decision not only indicates that she accepts responsibility for her loved ones, but probably also that she realizes, just like her father did, that "you do not liberate a country by standing on the soil of another". She probably realizes that the limiting problems of her society will not be solved by her escape, but by her active involvement in them.

The strength and resilience of the female characters in the novel and the possibility of misperceiving them as helpless victims are revealed in their identification with the weeping willow, that tree that looks to Najwa "like a woman with her hair down" and "when hit by the breeze, its colour got lighter, turned silver ... and the leaves swayed happily," yet some "idiot" might see it as sad and weeping (252). Faqir's choice of willows for her title, the way she describes them, and her assertion that they "don't weep" not only communicate an Arabic perception of the trees, but also a strong metaphor that captures the essence of her female characters. A Weeping Willow is sometimes also called Um Alsho'or, invoking the image of a beautiful woman with an abundance of flowing hair, and this is exactly how Najwa sees it, a woman 'with her hair down', suggesting a sense of beauty and even freedom. This image, incidentally, as Bilal Tawfiq Hamamra argues, contrasts with the "Willow Song" Desdemona sings in Shakespeare's Othello to communicate her grief and her sense of oppression and impending tragedy. The image also renders erroneous any comparison between the main female characters in Willow Trees Don't Weep and "the passivity and oppressing submission that Shakespeare bestowed on ... Desdemona" (222). ${ }^{1}$

In Arabic culture and since ancient times, willow trees have always been valued for their protective shade and for their medicinal and healing properties (Salicaceae - Salicacées n.p.). They have very long roots which allow them to both tolerate many types of soil and also prevent 
soil erosion; and they provide excellent shade (This Old House Review Team n.p.). They thrive better near water, but they are also tolerant to and can survive periods of drought ("Weeping Willow: Salix Babylonica" n.p.). Najwa and her grandmother endured hardships and devastating experiences, but, like willow trees they endured, "clung to the soil" (252), survived and protected and nurtured their loved ones. Raneen, however, is a different case. Unlike Mama Zainab, she had no sense of self except that derived from the presence of her husband, and unlike Najwa, she did not seek self-knowledge after his departure. Her choice to uproot herself from her community and traditions was a defiant reaction born out of resentment not of a solid sense of self. This is why, though she had her own brand of strength and tried to nurture and protect her daughter, as argued above, she eventually 'withered' and 'dried up like a date'.

It is probably worth mentioning here that Willow Trees Don't Weep, like most of Faqir's novels, is heavily influenced and informed by her own life experiences. She describes herself in "Granada: Migration, Hybridity and Transcultural Encounters", as "an expatriarch [sic], a woman who left her country because of domestic, political, and intellectual policing" (70). Though the term she coins is a play on words to signal her exit or escape from her country and its prevailing patriarchal system, the 'patriarch' which symbolizes this system and which she 'exes' here is her father, "a reluctant tyrant" (Bower 11) who imposed on her and her siblings "institutional religion", treated them as "cadets", "forced [her] to wear the veil" and into a marriage that turned "disastrous" and ended in divorce and her loss of the custody of her son. Yet, in spite of the fact that she declares that she left Jordan because of her father and because "he wanted me to be someone I was not" (Moore 2-3), she also regrets that her father, being a leading member of Hizbul Tahrir, was absent most of her childhood and adulthood. His patriarchal attitude and his absence were things that she could never understand, but as he gets older, "the urge to explore his decisions and understand him becomes stronger" for her. It is interesting that she wrote Willow Trees Don't Weep as "an attempt to understand and perhaps forgive my father" (Bower 11), and it seems that she did understand and forgive him since the novel is dedicated to him. It can be safely assumed, then, that the relationship between Najwa and Omar and their journeys of understanding and reconciliation to some extent reflect Faqir's relationship with her father and her own journey of understanding and forgiveness. It can be also assumed that Faqir's heavy-handed critique and exposure of oppressive social and cultural beliefs and practices in her country is "a form of writing back to patriarchy," blaming "women's grievances," including her own grievances, "on some derogative attitudes to women in the tradition" (Suyoufie 247). However, this heavy-handed critique of her culture of origin causes Faqir to fall in one of the pitfalls of her liminal position as an Anglophone Arab woman writer. Leaving Jordan where she "felt incarcerated" to escape her patriarchal father, Faqir found that "in England you could do whatever you want, be whoever you want" ("Granada" 71). For her England/West became, in the words of Rasheed El-Enany, a "space of Freedom ... a place of refuge from repression at home" (184). This is certainly reflected in Willow Trees Don't Weep where Faqir's grievances are generalized: Najwa, portrayed as harassed and oppressed in Jordan, finds in England support and freedom to travel, to work and even to have her first sexual experience. The implied comparison between traditional, oppressive Jordan/East and modern, liberal England/West, strongly suggests, Yasmina Djafri argues, that Faqir adopts "a neo-orientalist discourse" and is "tolerant to Western views and perceptions" (107). It is regrettable that this perpetuation of Orientalist views, even if unconscious, does seem to overshadow and undermine the humanizing odyssey of her two major characters. 
To conclude, the post-9/11 political and military upheaval resulted in a neo-Orientalist wave that centered its interest on the Arab/Muslim world, breathing new life in a Western hegemony based on Othering and the binary position of the 'superior West' and the 'inferior, backward East'. Center-stage in the neo-Orientalist, as in classical orientalist, discourse and the tug of war over superiority and dominance between West and East is the Muslim Arab woman who is represented as the victim to be saved from patriarchal and religious oppression. Yet, the crucial difference between classical Orientalism and neo-Orientalism is the authoritative voice of the neo-Orientalists who are mostly Middle Eastern/Muslim writers, especially women writers, and whose representations of their cultures and traditions are considered 'authentic'. These writers are caught in a dilemma: whether they write to critique their traditions and cultures to bring about favorable change, or succumb to the dictates of a publishing industry that caters for the taste of a Western consumer culture thirsty for the different and the exotic, they may fall in the trap of perpetuating Orientalist stereotypes of the Arab and Muslim world. Their work thus may not only be exploited in the service of Western hegemony, but may also suffer reductionist interpretations of meaning and message.

Fadia Faqir's Willow Trees Don't Weep clearly reflects this dilemma. Faqir intended the novel to be an odyssey, a journey of initiation, illumination and transformation that heals and humanizes her characters. Her heroine, Najwa, and her father, Omar, go on spatial and inner journeys in search of self, a position in their world and a meaning to their lives. Their plunge in the darkness of devastating external and internal experiences brings them face to face with their worst and better selves, but they finally emerge enlightened and capable of healing and forgiving. However, the universal human significance of their journeys is overshadowed by Faqir's preoccupation with and over-emphasis on issues of patriarchy and gender relations in her Arab society which seep into and seem to invite an Orientalist reading of the novel. As one of the Anglophone Arab women writers whose work is in demand in the West, Faqir is peculiarly positioned. Writing about patriarchy and gender problems in her Arab Muslim society she runs the risk of her work being marketed and manipulated to feed Western preconceived views. Yet, the alternative is to be silent about problems that she considers urgent and in need of reform. Finding a balance between these two contending options is a challenge. Perhaps by allowing Najwa to choose to go back to her country Faqir is heading towards finding that balance, which remains to be seen in her future novels.

\section{Notes}

${ }^{1}$ For a more detailed analysis of how Faqir uses the willow tree to challenge Shakespeare's representations of women in Othello and Cymbeline, see also Hussein Alhamamdeh, "'Shakespeare Had the Passion of an Arab': The Appropriation of Shakespeare in Fadia Faqir's Willow Trees Don't Weep," Critical Survey, vol. 30, no. 4, Dec. 2018, pp. 1-21. 


\section{Works Cited}

Alfred, Lord Tennyson, “Ulysses”. https://www.poetryfoundation.org/poems/45392/ulysses.

Alhamamdeh, Hussein. "'Shakespeare Had the Passion of an Arab': The Appropriation of Shakespeare in Fadia Faqir's Willow Trees Don't Weep," Critical Survey, vol. 30, no. 4, Dec. 2018, pp. 1-21.

Alrasheed, Khalid M. "Invisible Humans, Visible Terrorists: U.S. Neo-Orientalism Post 9/11 and Representations of the Muslim World." PhD Diss. Purdue University, West Lafayette, Indiana, 2015. www.proquest.com/openview/755e2fa8171277c248766adb6eb4f51c/. Accessed $8^{\text {th }}$ Sep. 2021.

Altawiji, Mubarak. "Neo-Orientalism and the New Imperial Thesis: Post 9/11 U.S. and Arab World Relations.” Arab Studies Quarterly, vol. 36, no. 4, Fall 2014, pp. 313-323.

Amireh, Amal. "Publishing in the West: Problems and Prospects for Arab Women Writers." $A l$ Jadid: A Review and of Record of Arab Culture and Arts, vol. 2, no. 10, August 1996. http://leb.net/-algadid/features/0210amireh.html. Accessed 6th March, 2021.

Behdad, Ali and Juliet Williams. "Neo-Orientalism." In Globalizing American Studies, edited by Brian T. Edwards and Dilip Parameshwar Ganokar. Chicago and London: University of Chicago Press, 2010, pp. 283-299.

Bhabha, Homi. The Location of Culture. London and New York: Routledge, 1994.

Bower, Rachel. Interview with Fadia Faqir, 23 March, 2010. Journal of Postcolonial Writing, vol. 48, no.1, 2012, pp. 3-12. DOI: 10.1080/17449855.2011.569380. Accessed $31^{\text {st }}$ Jan. 2018.

Bush, Laura. "Text: Laura Bush on Taliban Oppression of Women." November 17, 2001. https://www.washingtonpost.com/wpsrv/nation/specials/attacked/transcripts/laurabushtext_111701.html. Accessed a0th Sept. 2021.

Campbell, Joseph. The Hero with a Thousand Faces, Commemorative Edition. Princeton and Oxford: Princeton University Press, 2004.

Cayeux, Sophie. "Willow Trees Don't Weep by Fadia Faqir." 23 July, 2015. https://www.goodreads.com/review/show/1342906842?book_show_action=true\&from_r eview_page Accessed $1^{\text {st }}$ Dec. 2020.

Dabashi, Hamid. "Native Informers and the Making of the American Empire." Al Ahram Weekly, June 1, 2006. https://www.meforum.org/campus-watch/10542/native-informers-and-themaking-of-the-american-empire. Accessed $7^{\text {th }}$ Sept. 2021.

Darraj, Susan Muaddi. "Writing Relocation: Arab Anglophone Literature of the Last Decade." Iowa Journal of Cultural Studies, 2, Fall 2002, pp. 123-130.

---. Scheherazade's Legacy: Arab and Arab American Women on Writing. Westport, Connecticut and London: Praeger, 2004. 
Djafri, Yasmina. "Interrogating the Native's Otherness in Willow Trees Don't Weep by Fadia Faqir." In The Poetics of the Native, edited by Yosra Amraoui and Bootheina Majoul. Newcastle: Cambridge Scholars Publishing, 2021, pp. 95-108.

El-Enany, Rasheed. Arab Representations of the Occident: East-West Encounters in Arabic Fiction. New York and London: Routledge, 2006.

El-Miniawi, Nayera. "The Crisis of Identity in My Name is Salma." Fikr Wa Ibda', Jan. 2016, pp. https://www.researchgate.net/publication/313350785_The_Crisis_of_Identity_in_My_Na me_is_Salma/citation/download. Accessed 14 Feb. 2020.

Estés, Clarissa Pinkola. "Introduction to the 2004 Commemorative Edition: What Does the Sould Want?" in Joseph Campbell, The Hiro with a Thousand Faces. Princeton and Oxford: Princeton University Press, 2004, pp. xxiii-lxv.

Faqir, Fadia. "Granada: Migrations, Hybridity, and Transcultural Encounters." In Adventuring in the Englishes: Language and Literature in a Postcolonial Globalized World, edited by Ikram Ahmed Elsherif and Piers Michael Smith. Newcastle upon Tyne: Cambridge Scholars Publishing, 2013, pp. 70-78.

---. Willow Trees Don't Weep. London: Heron Books, 2014.

Hamamra, Bilal Tawfiq. A Reference to Shakespeare's Othello in Fadia Faqir's Willow Trees Don't Weep.” ANQ: A Quarterly Journal of Short Articles, Notes, and Reviews, vol. 32, no. 4, 2019, pp. 222-224.

Lewis, Bernard. What Went Wrong? The Clash between Islam and Modernity in the Middle East. New York: Harper Perennial, 2003.

Moore, Lindsey. "'You Arrive at $a$ Truth, Not the Truth': An Interview with Fadia Faqir." Postcolonial Text, vol. 6, no. 2, 2011, pp. 1-13. https://www.postcolonial.org. Accessed $10^{\text {th }}$ February, 2019.

Ouahmiche, Ghania and Dallel Sarnou. "Voices of Errancy, Spaces of Silenc and Traces of Writing in Narratives of Fadia Faqir, Leila Aboulela and Assia Djebar." International Journal of Arabic-English Studies (IJAES), vol. 16, 2015-2016, pp. 145-163. www.ijaes.net/Article?FullText/8? volume $=16 \&$ issue $=1$

Paul, Sourav and Shri Krishan Rai. "Willow Trees Don't Weep." Asian Journal of Women's Studies, vol. 26, no. 1, 2020, pp. 132-136. https://doi.org/10.1080/12259276.2020.1717077. Accessed 20 ${ }^{\text {th }}$ February, 2021.

Rosenberg, Donna. World Mythology: An Anthology of Great Myths and Epics. New York: McGraw-Hill, 1994.

Rosida, Ida and Aini Soraya. "Gender Relation in Willow Trees Don't Weep Novel (2014) by Fadia Faqir: A Feminist Literary Analysis." Insaniyat: Journal of Islam and Humanity, vol. 2, no. 1, Nov. 2017, pp. 13-28.

"Salicaceae - Salicacées." Arab Encyclopedia. http://arab-ency.com.sy/detail/6778. Accessed $17^{\text {th }}$ Sept. 2021. 
Said, Edward W. Orientalism: Western Conceptions of the Orient. London: Penguin Books, 1978/1994.

Suyoufie, Fadia. "The Appropriation of Tradition in Selected Works of Contemporary Arab Women Writers." Journal of Arabic Literature, vol. 39, 2008, pp. 216-249.

This Old House Review Team. This Old House. "Everything You Need to know about Weeping Willow Trees." https://www.thisoldhouse.com/gardening/21332451/weeping-willow accessed $18^{\text {th }}$ Feb., 2021.

Webb, Flemmich. "Willow Trees Don't Weep - Book Review: 'A Search for Meaning that Goes Nowhere'." Independent, 22 April, 2014. https://www.independent.co.uk/artsentertainment/books/reviews/willow-trees-don-t-weep-fadia-faqir-book-review-searchmeaning-ends-going-nowhere-9273472.html Accessed 18th Feb., 2021.

"Weeping Willow: Salix Babylonica." Arbor Day Foundation. https://www.arborday.org/trees/treeguide/TreeDetail.cfm?ItemID=938. Accessed $19^{\text {th }}$ Feb. 2021.

Zaghmout, Fadi. “Willow Trees Don't Weep: Interviewing Fadia Faqir.” $30^{\text {th }}$ August, 2015. https://fadizaghmout.com/2015/08/30/willow-trees-dont-weep-interviewing-fadia-faqir/ accessed $15^{\text {th }}$ Feb. 2021. 